\title{
PATHOPHYSIOLOGICAL STUDY OF IRON DEFICIENCY ANEMIA IN ADOLESCENCE
}

\author{
TAKAAKI FUJII \\ Department of Internal Medicine, Saiseikai Utsunomiya Hospital \\ and School of Medicine, Keio University \\ YASUO MATSUKI and MITSUTO HASEGAWA \\ Department of Internal Medicine, School of Medicine, Keio University \\ Tokyo, Japan
}

(Received for publication July 27, 1968)

As for the pathophysiological study of iron deficiency anemia in adolescence, very few investigations have been carried out except for those in connection with iron metabolism.

In this study, an attempt has been made to clarify the pathophysiological pattern of iron deficiency anemia in adolescence from the standpoint of other factors than iron metabolism, namely vitamin $\mathrm{E}$, ovarian function and unpalpable splenomegaly.

Vitamin $\mathrm{E}$ is well known to have a close relationship with the endocrine system. For instance, the reduced function of the endocrine organs, mainly sex glands, has been reported in vitamin E deficient rats (Evans 1922, Bisceglie 1928, Martin 1939).

On the other hands, close relationship between vitamin $\mathrm{E}$ and anemia has also been reported by several investigators such as Dinning (1957) ${ }^{1}$ and Porter (1966), 2 who noted remarkable anemia in vitamin $\mathrm{E}$ deficient monkeys under observation.

Adolescence is a period when the function of the endocrine system becomes quite active, and iron deficiency anemia is also frequently observed in this period. Accordingly the investigations in this study were made to clarify the role of vitamin $\mathrm{E}$ in iron deficiency anemia during adolescence.

Loss of iron during the menstrual period has frequently been singled out as being a main cause of iron deficiency anemia in adolescent females. As we have occasionaly encountered cases of iron deficiency anemia in adolescent females in 
daily clinic which could not be explained etiologically by iron loss alone, the effect of ovarian function on this anemia was studied.

Splenomegaly has occasionaly been reported ${ }^{3}$ in cases of iron deficiency anemia, however the pathophysiology of the splenomegaly in this anemia remains unclear.

For the above reasons, the pathophysiological pattern of iron deficiency anemia in adolescence was investigated from the standpoint of the three aforementioned factors: vitamin $\mathrm{E}$, ovarian function and unpalpable splenomegaly.

\section{MATERIALS}

Japanese patients with iron deficiency anemia, male and female, ranging in age from 14 to 19 were studied. The hemoglobin level in the male and female patients were $10.9 \mathrm{~g}$ per $100 \mathrm{ml}$ and $9.9 \mathrm{~g}$ per $100 \mathrm{ml}$ respectively. The serum iron level in both patients were below $70 \mathrm{mcg}$ per $100 \mathrm{ml}$. The patients who were considered to have gastrointestinal or genital hemorrhage, parasite infection, thyroid glands disorder, were excluded from the present studies. The spleen was not palpable in all cases.

Healthy Japanese adults ranging in age from 20 to 50 and healthy adolescents, from 14 to 19, were examined as the control groups. Hemoglobin level and serum iron level of these groups were above $14.0 \mathrm{~g}$ per $100 \mathrm{ml}$ in males, $13.0 \mathrm{~g}$ per $100 \mathrm{ml}$ in females. Serum iron level were above $80 \mathrm{mcg}$ per $100 \mathrm{ml}$.

1. Serum vitamin $\mathrm{E}$ level and dialuric acid hemolysis test were determined in 100 healthy adults (males 50, females 50) and 51 healthy adolescents (males 29 , females 22). These were determined in 65 cases with iron deficiency anemia in adolescence (males 22, females 43 ) before treatment and 30 cases (males 13, females 17) both before and after treatment.

2. Urinary excretion of 17-KS, 17-OHCS, estrogen and pregnanediol were measured in both follicular and luteal phase of 10 healthy female adolescents and in 15 cases with iron deficiency anemia in adolescence before treatment and 8 cases both before and after treatment.

3. Basal body temperature was measured in 21 cases with iron deficiency anemia in adolescence during iron therapy.

4. Tomographic examinations for unpalpable splenomegaly were carried out in 45 healthy adults (males 15, females 30 ) and 47 healthy adolescents (males 25 , females 22). This examination was also carried out in 96 cases (males 34, females 62) with iron deficiency anemia in adolescence before treatment and 36 cases (males 19, females 17) both before and after treatment. 


\section{METHOD}

Administration of iron preparation - Four hundred fifty milligrams of ferrous fumarate per day was administered orally for 6 to 8 weeks.

Measurement of hemoglobin level - Hemoglobin level was determined by Cyanmethemoglobin method.

Measurement of serum iron level - Serum iron level was determined by Basophenanthrolin method.

Measurement of serum vitamin $E$ level - Serum vitamin $E$ level was determined by Rindi method as described below. Two milliliters of serum was mixed with $1.0 \mathrm{ml}$ of $10 \% \mathrm{v} / \mathrm{v}$ ascorbic acid, $0.2 \mathrm{ml}$ of $50 \% \mathrm{v} / \mathrm{v} \mathrm{KOH}$ and $3.0 \mathrm{ml}$ of ethylalcohol. The mixture was saponified at $90^{\circ} \mathrm{C}$ for 15 minutes. After immediately cooling the mixture by placing it in ice bath, $6.0 \mathrm{ml}$ of xylen was added. After shaking for 8 minutes the mixture was centrifuged at $3000 \mathrm{rpm}$ for 10 minutes. The xylen layer was collected and read by colorimeter at $460 \mathrm{~m} \mu$ for correction of carotin value. Then $3.0 \mathrm{ml}$ of xylen layer was mixed with $1.0 \mathrm{ml}$ of $0.3 \% \alpha, \alpha^{\prime}$-Dipyridyl and $1.0 \mathrm{ml}$ of $0.12 \% \mathrm{FeCl}_{3} \cdot 6 \mathrm{H}_{2} \mathrm{O}$. Exactly 2 minutes after mixing, the mixture was read at $520 \mathrm{~m} \mu$.

Blank and standard solutions were measured simultaneously by the same procedure.

Dialuric acid hemolysis test - Dialuric acid hemolysis test was carried out by Rose and György ${ }^{4}$ method. The oxalated blood $0.03 \mathrm{ml}$ was mixed with $5.0 \mathrm{ml}$ of saline phosphate buffer solution and the mixture was centrifuged at $2000 \mathrm{rpm}$ for 10 minutes. The supernatant was discarded and the blood cell suspension was made by adding $5.0 \mathrm{ml}$ of saline phosphate buffer solution. One milliliter of the blood cell suspension was placed into 3 tubes. One milliliter of dialuric acid was added to the first and second tubes and $1.0 \mathrm{ml}$ of saline phosphate to the third tube. These tubes were incubated at $37^{\circ} \mathrm{C}$ for 1 hour and then left at room temperature for 1 hour. Five milliliters of saline phosphate buffer solution was added to the first and third tubes, and $5.0 \mathrm{ml}$ of distilled water to the second tube. After mixing well, the mixtures of all three tubes were centrifuged at $2000 \mathrm{rpm}$ for 10 minutes. The light absorbence unit of all supernatants was read at 415 $\mathrm{m} \mu$. Percent hemolysis was calculated according to the formula below. When hemolysis occured at any rate, the reaction was defined as positive; no hemolysis was defined as negative.

$$
\% \text { Hemolysis }=\frac{\text { tube } 1-\text { tube } 3}{\text { tube } 2-\text { tube } 3} \times 100
$$


Measurement of urinary excretion of hormone-

17-KS: 17-KS was measured by Director method as modified by Kambegawa.

17-OHCS: 17-OHCS was measured by Glenn-Nelson method as modified by Kambegawa.

Estrogen: Estrogen was measured by Brown method as modified by Kambegawa.

Pregnanediol: Pregnanediol was measured by Klopper method as modified by Kambegawa.

Determination of the basal body temperature-The basal body temperature (B.B.T.) was measured by Matsuda thermometer, between 6 and 8 o'clock every morning.

Roentogenographic examination of the spleen-

The procedure: Tomography was taken 5 minutes after intake of a liquid mixture composed of tartaric acid $1.5 \mathrm{~g}$, sodium bicarbonate $2.0 \mathrm{~g}$ and distilled water $30 \mathrm{ml}$ in fasting state. Splenic area was estimated by tracing splenic shadow on tomograph with planimeter.

Roentogenographic conditions: Voltage $70 \mathrm{KVP}$ for $17 \mathrm{~cm}$ in anteriorposterior diameter, ampere $100 \mathrm{~mA}$, time 2 seconds, focus film distance $145 \mathrm{~cm}$, $45^{\circ}$ exposure angle for layer at 6 and $8 \mathrm{~cm}$ from abdominal wall in prone position.

\section{RESULTS}

\section{Vitamin $\mathrm{E}$}

1. Before treatment

Serum vitamin $E$ level - The serum vitamin $\mathrm{E}$ level was $1.25 \pm 0.12 \mathrm{mg}$ per $100 \mathrm{ml}$ in healthy adults, $1.00 \pm 0.12 \mathrm{mg}$ per $100 \mathrm{ml}$ in healthy adolescents and $0.87 \pm 0.17 \mathrm{mg}$ per $100 \mathrm{ml}$ in patients with iron deficiency anemia in adolescence. Serum vitamin $E$ level in healthy adolescents was statistically lower than that of healthy adults $(p<0.01)$.

More marked fall of vitamin $\mathrm{E}$ level was observed in cases of iron deficiency anemia in adolescence as compared with that of healthy adults $(\mathrm{p}<0.01)$ and healthy adolescents $(p<0.01)$. (Table 1 )

Dialuric acid hemolysis test - No positive dialuric acid hemolysis test was observed in any of healthy adults. Dialuric acid hemolysis test in healthy adolescents and cases with iron deficiency anemia in adolescence was positive in 11 out of $51(21.5 \%)$ and 28 out of $65(43.1 \%)$ respectively (Table 1 ).

2. After treatment by iron therapy

Serum vitamin $E$ level - The serum vitamin E level showed statistically 
Table 1

Serum vitamin $E$ level and dialuric acid hemolysis test

\begin{tabular}{|c|c|c|c|c|c|}
\hline & & Cases & $\begin{array}{l}\text { Serum Vit. } \mathbf{E} \\
\text { level } \mathrm{mg} / \mathrm{dl}\end{array}$ & $\mathbf{p}$ & $\begin{array}{l}\text { Dialuric acid } \\
\text { hemolysis test } \\
\text { positive cases }\end{array}$ \\
\hline & Healthy adults & 100 & $1.25 \pm 0.12$ & \multirow{3}{*}{$\begin{array}{l}<0.01 \\
<0.01\end{array}$} & $0(0 \%)$ \\
\hline & Healthy adolescents & 51 & $1.00 \pm 0.12$ & & $11(21.5 \%)$ \\
\hline & $\begin{array}{l}\text { Iron deficiency anemia } \\
\text { in adolescence }\end{array}$ & 65 & $0.87 \pm 0.17$ & & $28(43.1 \%)$ \\
\hline \multirow[t]{3}{*}{ Male } & Healthy adults & 50 & $1.34 \pm 0.10$ & \multirow{3}{*}{$\begin{array}{l}<0.01 \\
<0.01\end{array}$} & $0(0 \%)$ \\
\hline & Healthy adolescents & 29 & $1.01 \pm 0.12$ & & $6(20.7 \%)$ \\
\hline & $\begin{array}{l}\text { Iron deficiency anemia } \\
\text { in adolescence }\end{array}$ & 22 & $0.87 \pm 0.15$ & & $10(45.5 \%)$ \\
\hline \multirow[t]{3}{*}{ Female } & Healthy adults & 50 & $1.17 \pm 0.13$ & \multirow{3}{*}{$\begin{array}{l}<0.01 \\
<0.01\end{array}$} & $0(0 \%)$ \\
\hline & Healthy adolescents & 22 & $0.99 \pm 0.11$ & & $5(22.7 \%)$ \\
\hline & $\begin{array}{l}\text { Iron deficiency anemia } \\
\text { in adolescence }\end{array}$ & 43 & $0.87 \pm 0.06$ & & $18(41.8 \%)$ \\
\hline
\end{tabular}

significant increase from $0.84 \pm 0.14 \mathrm{mg}$ per $100 \mathrm{ml}$ of pretreatment value to $1.07 \pm 0.20 \mathrm{mg}$ per $100 \mathrm{ml}$ after treatment along with improvement of anemia $(\mathrm{p}<0.01)$.

Dialuric acid hemolysis test - Dialuric acid hemolysis test positive cases decreased from $14(46.6 \%)$ to $2(6.6 \%)$ out of 30 cases after treatment along with improvement of anemia.

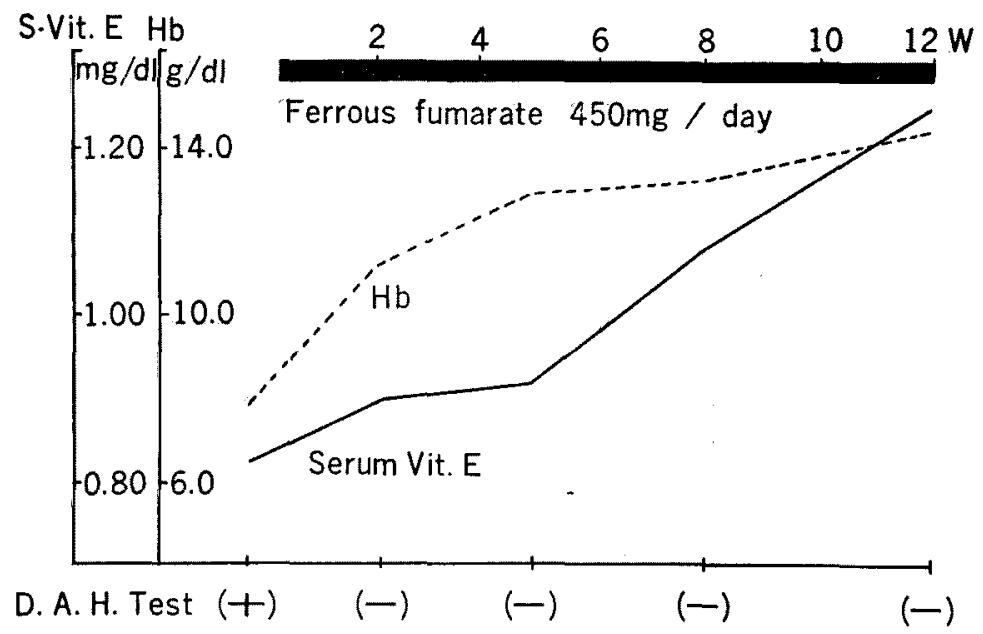

Fig. 1. Case 1. (14 Yrs. 우). 
A representative case was described as follows: Case 1. Fourteen-year-old female case with iron deficiency anemia (Fig. 1).

Before treatment the laboratory data of the patient were erythrocyte count 2.95 million per $\mathrm{cmm}$, hemoglobin level $7.5 \mathrm{~g}$ per $100 \mathrm{ml}$, hematocrit $28 \%$, serum iron level $39.5 \mathrm{mcg}$ per $100 \mathrm{ml}$, serum vitamin E level $0.82 \mathrm{mg}$ per $100 \mathrm{ml}$, and positive dialuric hemclysis test $(3.06 \%)$.

Along with recovery of anemia by iron therapy increase of serum vitamin $\mathrm{E}$ level was observed. Dialuric acid hemolysis test also turned negative 2 weeks after administration of iron preparation.

\section{Ovarian function}

1. Before treatment

Urinary excretion of 17-KS, 17-OHCS, estrogen and pregnanediol - Decreased urinary excretion of 17-KS, 17-OHCS, estrogen and pregnanediol in follicular phase and 17-OHCS and pregnanediol in luteal phase were observed in cases with iron deficiency anemia in adolescence as compared with those of healthy female adolescents. Among these decrease of urinary excretion of estrogen in follicular phase was particularly prominent (Table 2).

Table 2

Urinary excretion of $1 \%-K S, 1 \%-O H C S$, estrogen and pregnanediol before treatment

\begin{tabular}{|c|c|c|c|c|}
\hline & & $\begin{array}{l}\text { Healty } \\
\text { adolescents } \\
\text { (10 cases) }\end{array}$ & $\begin{array}{c}\text { Iron def. anemia } \\
\text { in adolescence } \\
\text { (15 Cases) }\end{array}$ & $\mathrm{p}$ \\
\hline \multicolumn{5}{|l|}{ Follicular phase } \\
\hline $17 \mathrm{KS}$ & $\mathrm{mg} / \mathrm{day}$ & $7.51 \pm 1.71$ & $4.65 \pm 1.85$ & $<0.01$ \\
\hline 17 OHCS & $\mathrm{mg} / \mathrm{day}$ & $4.45 \pm 1.53$ & $2.46 \pm 1.91$ & $<0.05$ \\
\hline Estrogen & $\mathrm{mcg} / \mathrm{day}$ & $30.78 \pm 17.40$ & $9.41 \pm 9.75$ & $<0.01$ \\
\hline Pregnanediol & $\mathrm{mg} /$ day & $1.49 \pm 1.09$ & $0.46 \pm 0.33$ & $<0.01$ \\
\hline \multicolumn{5}{|l|}{ Luteal phase } \\
\hline $17 \mathrm{KS}$ & $\mathrm{mg} /$ day & $6.35 \pm 1.85$ & $5.55 \pm 3.53$ & $>0.05$ \\
\hline 17 OHCS & $\mathrm{mg} /$ day & $3.71 \pm 1.99$ & $2.65 \pm 2.78$ & $<0.05$ \\
\hline Estrogen & $\mathrm{mcg} / \mathrm{day}$ & $18.68 \pm 8.27$ & $13.51 \pm 14.46$ & $>0.05$ \\
\hline Pregnanediol & $\mathrm{mg} / \mathrm{day}$ & $3.17 \pm 1.99$ & $0.98 \pm 0.16$ & $<0.05$ \\
\hline
\end{tabular}

Basal body temperature - Normal biphasic curve of basal body temperature was observed in none of cases with iron deficiency anemia during adolescence at the beginning of treatment. Ten out of 21 cases showed low monophasic curve of basal body temperature indicating remarkable ovarian dysfunction (Fig. 2). 


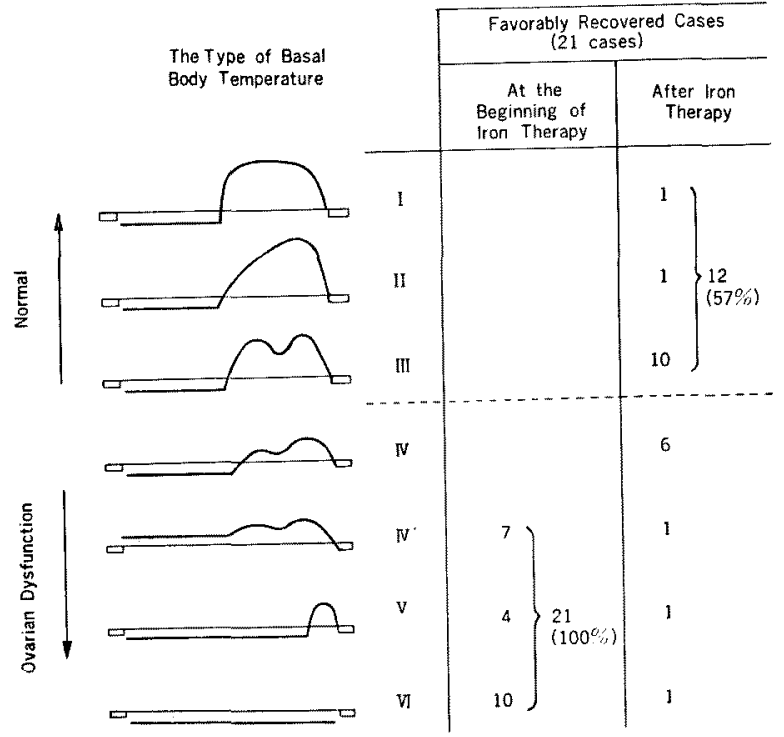

Fig. 2. Changes of basal body temperature curve by iron therapy (Iron deficiency anemia in adolescence).

2. After treatment by iron therapy

Urinary excretion of $17-K S, 17-O H C S$, estrogen and pregnanediol - Increased urinary excretion of 17-KS, 17-OHCS, estrogen and pregnanediol was observed in either follicular and luteal phase in cases with iron deficiency anemia in adolescence following recovery from anemia by iron therapy. Particularly increase of urinary excretion of estrogen in follicular phase and pregnanediol in luteal phase was remarkable (Table 3).

Basal body temperature - Basal body temperature curve indicated remarkable ovarian dysfunction in all cases at the beginning of treatment, which turned to normal biphasic curve in 12 out of 21 cases ( $57 \%$ ) following recovery from anemia with iron therapy.

A representative case was described as follows: Case 2. Seventeen-yearold female case with iron deficiency anemia (Fig. 3).

Laboratory data before treatment were erythrocyte count 2.96 million per $\mathrm{cmm}$, hemoglobin level $5.4 \mathrm{~g}$ per $100 \mathrm{ml}$, hematocrit $20 \%$, serum iron level $38 \mathrm{mcg}$ per $100 \mathrm{ml}$ and urinary excretion of $17-\mathrm{KS} 4.96 \mathrm{mg}, 17-\mathrm{OHCS} 3.29 \mathrm{mg}$, estrogen $6.5 \mathrm{meg}$, and pregnanediol $0.78 \mathrm{mg}$ per day. Basal body temperature showed low monophasic curve of ovarian dysfunction at the beginning of treatment.

Following recovery from anemia with iron therapy, urinary excretion of 


\section{Table 8}

Urinary excretion of 17-KS, 17-OHCS, estrogen and pregnanediol before and after iron therapy

(Iron deficiency anemia in adolescence)

\begin{tabular}{|c|c|c|c|c|}
\hline & & $\begin{array}{c}\text { Befor treatment } \\
\text { (8 Cases) }\end{array}$ & $\begin{array}{l}\text { After treatment } \\
\text { (8 Cases) }\end{array}$ & $\mathbf{p}$ \\
\hline \multicolumn{5}{|l|}{ Follicular phase } \\
\hline $17 \mathrm{KS}$ & $\mathrm{mg} /$ day & $4.02 \pm 1.67$ & $9.87 \pm 3.87$ & $<0.01$ \\
\hline 17 OHCS & $\mathrm{mg} / \mathrm{day}$ & $1.67 \pm 1.09$ & $3.07 \pm 1.51$ & $<0.01$ \\
\hline Estrogen & $\mathrm{mcg} / \mathrm{day}$ & $7.88 \pm 2.62$ & $23.47 \pm 19.23$ & $<0.01$ \\
\hline Pregnanediol & $\mathrm{mg} /$ day & $0.45 \pm 0.37$ & $0.79 \pm 0.28$ & $<0.05$ \\
\hline \multicolumn{5}{|l|}{ Luteal phase } \\
\hline $17 \mathrm{KS}$ & $\mathrm{mg} /$ day & $5.86 \pm 2.16$ & $7.70 \pm 3.15$ & $<0.01$ \\
\hline $17 \mathrm{OHCS}$ & $\mathrm{mg} / \mathrm{day}$ & $1.88 \pm 0.84$ & $2.78 \pm 1.10$ & $<0.01$ \\
\hline Estrogen & $\mathrm{mcg} / \mathrm{day}$ & $14.80 \pm 10.48$ & $28.39 \pm 13.16$ & $<0.05$ \\
\hline Pregnanediol & $\mathrm{mg} / \mathrm{day}$ & $0.94 \pm 1.23$ & $2.02 \pm 0.82$ & $<0.01$ \\
\hline
\end{tabular}
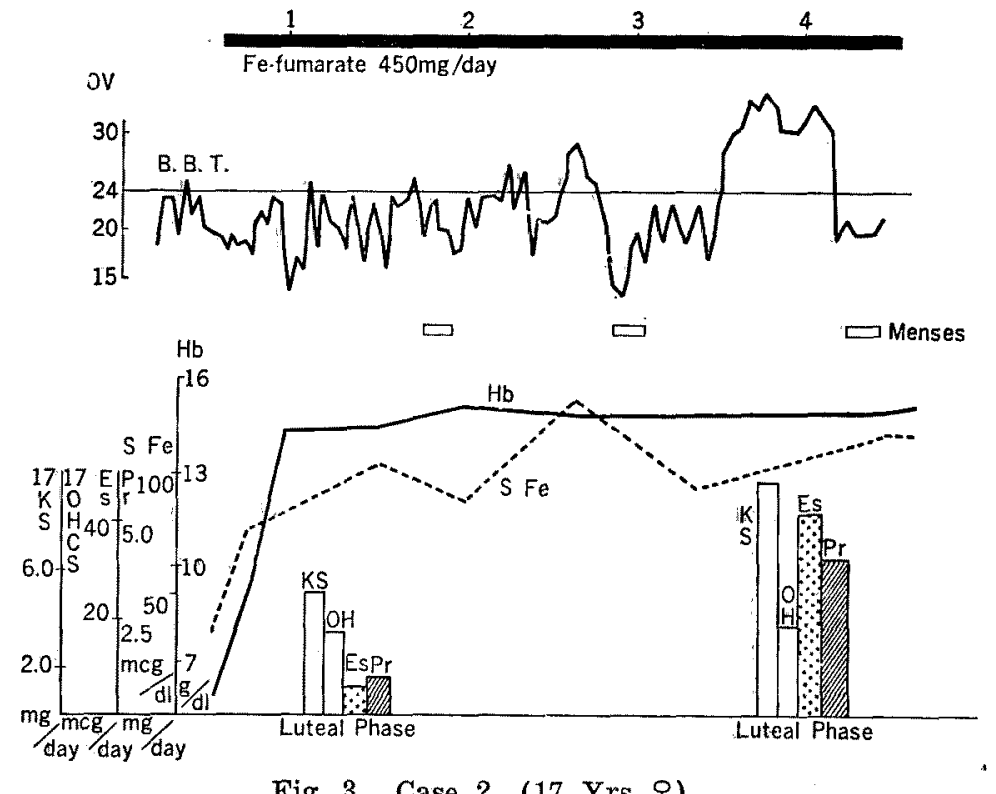

Fig. 3. Case 2. (17 Yrs. 우).

estrogen and pregnanediol in luteal phase remarkably increased. The basal body temperature also revealed improvement of ovarian function. 
III. Unpalpable splenomegaly

1. Before treatment

Tomographic examination revealed the splenic area of healthy adults to be $13.3 \pm 4.0 \mathrm{~cm}^{2}$. Accordingly unpalpable spleen with splenic area above $20 \mathrm{~cm}^{2}$ was defined as unpalpable splenomegaly.

Unpalpable splenomegaly was observed in 16 (males 8 , females 8) out of 47 healthy adolescents $(34.0 \%)$. Among then 4 healthy male adolescents $(8.5 \%)$ were proved to have large unpalpable spleen with splenic area above $30 \mathrm{~cm}^{2}$.

In 63 (males 37, females 26) of 96 cases (65.6\%) with iron deficiency anemia in adolescence unpalpable splenomegaly was demonstrated including 26 (males 20 , females 6 ) cases $(27.1 \%$ ) with fairly large unpalpable spleen with splenic area above $30 \mathrm{~cm}^{2}$. (see photograph)

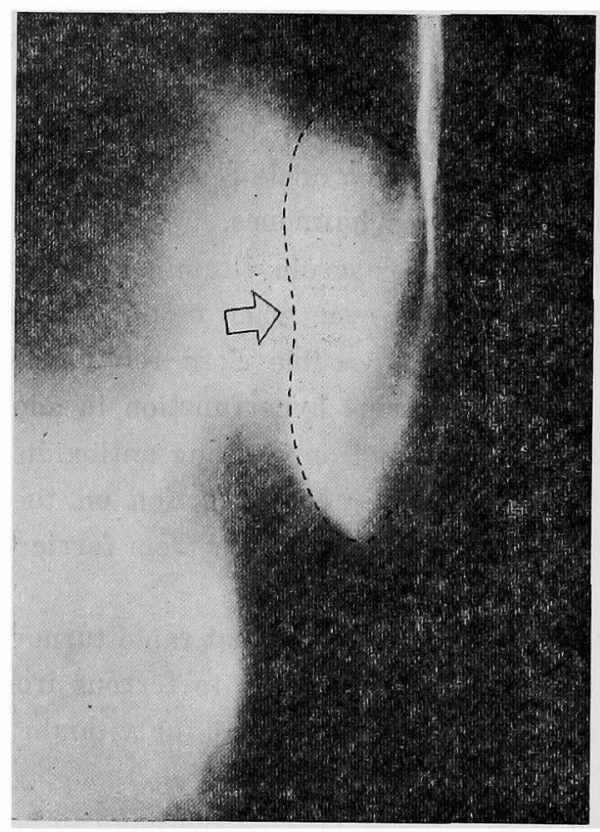

Photograph

Tomograph showing the size of unpalpable splenomegaly in iron deficiency anemia during adolescence.

Spleen area of this patient was $32.2 \mathrm{~cm}^{2}$.

2. After treatment by iron therapy

Reduction of splenic area to normal range (less than $20 \mathrm{~cm}^{2}$ ) was observed in 
11 (males 1 , females 10 ) out of 36 cases (30.6\%) with iron deficiency anemia in adolescence following iron therapy. Among those of which splenic size did not reduce into normal range, reduction of splenic size over $10 \mathrm{~cm}^{2}$ was observed in 8 (males 7 , females 1 ) out of 36 cases $(22.2 \%$ ). In short, $52.8 \%$ of cases with this anemia showed significant reduction of splenic area following iron therapy.

\section{DISCUSSION}

As to the cause of decreased serum vitamin $\mathrm{E}$ level in cases with iron deficiency anemia in adolescence, insufficient intake of dietary vitamin $\mathrm{E}$ and increased vitamin $\mathrm{E}$ requirement of the body may be considered as major factors.

Vitamin $\mathrm{E}$ was primarily discovered as an antisterility factor (Evans 1922, Sure 1932) and has been believed to be closely related to the endocrine function. It is known that pituitary and adrenal glands are extremely rich in vitamin $\mathrm{E}$ (Beckmann 1955).

Rapid growth of the body during adolescence is due to remarkably increased excretion of gonadotropin and sex hormones.

In our series of studies, lower serum vitamin $E$ level was found in healthy adolescents than in healthy adults even when no anemia was detected in any of them. These facts may indicate psssible close relationship between decreased serum vitamin $E$ level and endocrine hyperfunction in adolescence.

Vitamin $\mathrm{E}$ is known to have not only strong antioxidising action on unsaturated fatty acid but also to have reducing action on the heavy metals. ${ }^{5}$ For instance, reducing action of vitamin $\mathrm{E}$ on iron from ferric to ferrous iron is well known.

Ferrokinetic studies disclosed the fact that rapid turnover of iron metabolisin with frequent reduction of iron from ferric to ferrous iron occured in cases of iron deficiency anemia. ${ }^{6}$ Accordingly demand for vitamin $\mathrm{E}$ was considered to increase in cases of iron deficiency anemia.

Increased vitamin $\mathbf{E}$ level following iron therapy can be explained as follows. After recovery of anemia iron turnover is known to return to normal resulting in decreased demand for vitamin $E$ for reduction of iron. This decreased demand for vitamin $\mathrm{E}$ may be considered to increase serum vitamin $\mathrm{E}$ to healthy adolescent level.

Various other factors besides those mentioned above might also be taken into consideration in the relationship between iron and vitamin $\mathrm{E}$ deficiency and the increase of serum vitamin $E$ level following iron therapy. However, for sufficient 
explanation of those factors further investigations will be needed.

In our studies on iron deficiency anemia, positive dialuric acid hemolysis tests were also observed acompanied by low serum vitamin $\mathrm{E}$ level. This result was considered to be ascribed to lipoperoxidation on unsaturated fatty acid due to vitamin E deficiency. Rose, ${ }^{4}$ Dinning, ${ }^{1}$ Horwitt 7 and others postulated that increased fragility of red blood cells when treated with $\mathrm{H}_{2} \mathrm{O}_{2}$ or dialuric acid, observed in vitamin $\mathrm{E}$ deficient stage, was ascribed to red blood cells membranes weakened by lipoperoxidation. Decreased number of cases with positive dialuric acid hemolysis tests following iron therapy were considered due to reduced lipoperoxidation accompanying increase of serum vitamin $\mathrm{E}$ level.

Ovarian dysfunction and unpalpable splenomegaly observed in cases with adolescent iron deficiency anemia were another point of interest. The cause of these phenomena in this anemia was also considered more easily explainable in connection with change of serum vitamin $\mathrm{E}$ level.

Ovarian dysfunction observed in the pretreatment stage of iron deficiency anemia in adolescence improved greatly with recovery from anemia following iron therapy. Many reports have been made on sterility or other endocrine dysfunctions produced in vitamin $\mathrm{E}$ deficient rats or endocrine hyperfunction produced by administration of vitamin $E^{8,6,10, v_{1}}$ It is quite interesting that endocrinological change in this anemia went in parallel with the change of serum vitamin $\mathrm{E}$ level before and after iron therapy.

Unpalpable splenomegaly was observed in $34.0 \%$ of healthy adolescents without anemia. However, this incidence of unpalpable splenomegaly increased to $65.6 \%$ in adolescents with iron deficiency anemia. It is well known that fragile red blood cells have an important role in production of splenomegaly. In our studies dialuric acid hemolysis test positive reactions were observed in $21.5 \%$ of healthy adolescents without anemia. However, this incidense of positive dialuric acid hemolysis test was much higher in iron deficiency anemia during adolescence $(43.1 \%$ ) than in healthy adolescents.

Reduction of unpalpable splenomegaly was observed in $52 \%$ of the cases following iron therapy. This reduction of splenic size appeared to go parallel with increased serum vitamin $\mathrm{E}$ level and decreased incidence of positive dialuric acid hemolysis test following iron therapy. Marvin et al.12 reported shortened life span of the red blood cells in vitamin $\mathrm{E}$ deficient monkeys.

In short, increased fragility of red blood cells accompanied by decreased serum vitamin $\mathrm{E}$ level may play an important role in production of unpalpable splenomegaly in the cases of iron deficiency anemia during adolescence.

As to dietary deficicncy of vitamin $\mathrm{E}$, further comparative investigations 
will be needed on the contents of ordinary Japanese foods, paritcularly on the amount of unsaturated fatty acids and vitamin $\mathrm{E}$, with those of other countries. Ikehata demonstrated that intake of dietary vitamin $\mathrm{E}_{\boldsymbol{i}}$ ( $\boldsymbol{\alpha}$-tocopherol) of Japanese is lower than that of Americans (Table 4).

Table 4

Vitamin $E$ content of diet

\begin{tabular}{llrrrr}
\hline \multirow{2}{*}{ Diet } & \multirow{2}{*}{ Reference } & \multicolumn{2}{c}{ Lipid } & PUFA & \multicolumn{2}{c}{$\alpha$-Toc } & \multicolumn{1}{c}{$\alpha$-Toc(mg) } \\
& & \multicolumn{1}{c}{$(\mathrm{g})$} & \multicolumn{1}{c}{$(\mathrm{g})$} & \multicolumn{1}{c}{$(\mathrm{mg})$} & PUFA(g) \\
\hline U.S.A (Calculated)* & Harris (1963) & 145.9 & 24.2 & 14.9 & 0.62 \\
JAPAN (Calculated)** & Ikehata (1968) & 35.8 & 10.5 & 5.3 & 0.51 \\
JAPAN (Determined) & Ikehata (1968) & 43.6 & 12.4 & 5.2 & 0.42 \\
\hline
\end{tabular}

* Census in 1960, ** Census in 1964 (Ikehata 1968)

This fact may suggest a possible role of dietary vitamin $\mathrm{E}$ deficiency as one of the causes of decreased serum vitamin $\mathbf{E}$ level in healthy adolescents and iron deficiency anemia during adolescence in Japan.

Table 5

Pathophysiology of iron deficiency anemia in adolescence (Schema)

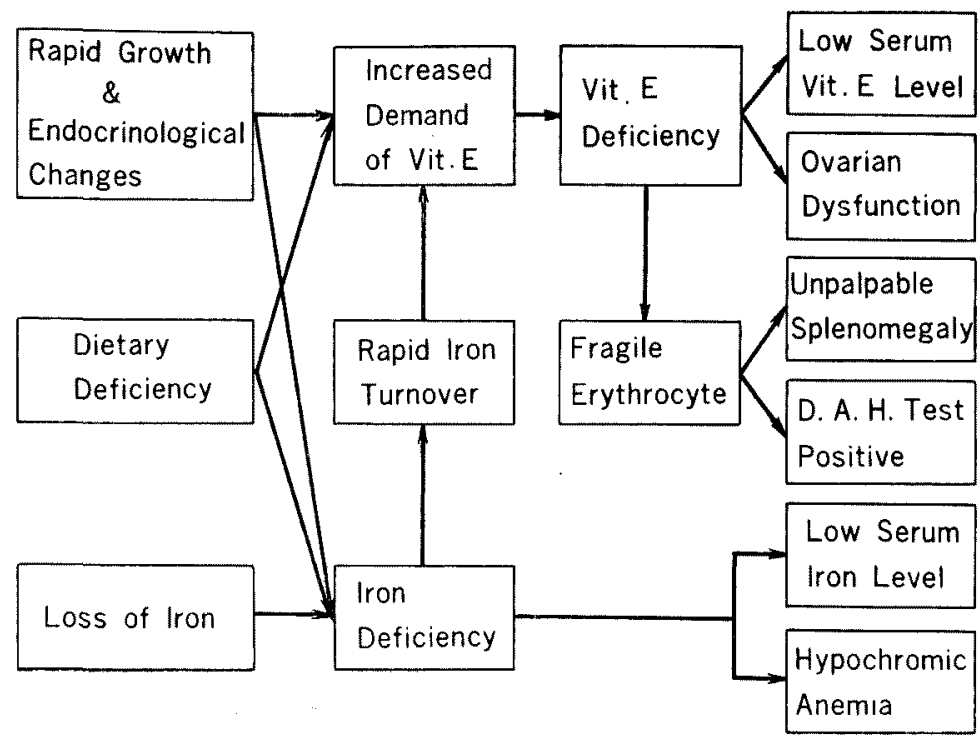


Our hypothesis in pathophysiology of iron deficiency anemia during adolescence was shown in Table 5 .

In summary, the pathophysiology of iron deficiency anemia in adolescence must be studied from various viewpoints, such as vitamin $\mathrm{E}$ deficiency, as well as iron deficiency.

\section{SUMMARY}

In order to elucidate the pathophysiology of iron deficiency anemia during adolescence, interrelationship among vitamin $\mathrm{E}$, ovarian function and unpalpable splenomegaly was studied in this anemia and following results were obtained.

1. The serum vitamin $\mathbf{E}$ level of patients with iron deficiency anemia in adolescence before treatment was $0.87 \pm 0.17 \mathrm{mg}$ per $100 \mathrm{ml}$ showing a remarkably low level as compared to $1.25 \pm 0.12 \mathrm{mg}$ per $100 \mathrm{ml}$ in healthy adults.

Dialuric acid hemolysis test in patients with iron deficiency anemia during adolescence before treatment was positive in $43.1 \%$. No positive dialuric acid hemolysis test was observed in any of the healthy adults.

Following iron therapy, increase of serum vitamin $\mathrm{E}$ level, decreased incidence of positive dialuric acid hemolysis test were observed accompanied with recovery from anemia.

2. In pretreatment stage of this anemia decreased urinary excretion of estrogen and pregnanediol with abnormal pattern of basal body temperature indicating ovarian dysfunction were observed. However, this ovarian dysfunction extremely improved with recovery from anemia following iron therapy.

3. In $65.6 \%$ of patients with iron deficiency anemia in adolescence unpalpable splenomegaly was observed by tomographic examination before treatment. However, reduction of splenic size was observed in $52.8 \%$ of the cases with recovery from anemia following iron therapy.

The role of vitamin $\mathrm{E}$ in connection with ovarian dysfunction and unpalpable splenomegaly in iron deficiency anemia during adolescence was discussed.

A part of this paper was presented in International Society of Hematology XIIth Congress, New York, September, 1968.

\section{REFERENCES}

1. Dinning, J. S. and Day, P. L.: Vitamin E deficiency in the monkey. 1. Muscular dystrophy, hematologic changes and the excretion of urinary nitrogenous constituents. J. Exp. Med., 105: 395-402, 1957. 
2. Porter, F. S. and Fitch, C. D.: Vitamin E deficiency in the monkey X. protoporphyrin and haeme synthesis by peripheral blood and bone marrow. Scand. J. Hemat., 3: 175-185, 1966.

3. Wintrobe, M. M.: Clinical Hematology. Lea \& Philadelphia, 1967. p. 594.

4. Rose, C. S. and Gyögy, P.: Specifity of hemolytic reaction in vitamin E-deficient erythrocytes. J. Physiol., 168: 414-420, 1952.

5. Morton, R. A.: Biochemistry of Quinones. Academic Press, London and New York, 1965. p. 263.

6. Bothwell, T. H. and Finch, C. A.: Iron Metabolism. Boston Little, Brown and Company, 1962. p. 180-219.

7. Horwitt, M. K, et al.: Effect of limited tocopherol intake in man with relationships to erythrocyte hemolysis and lipids oxidations. Amer. J. Clin. Nutr., 4: 408$419,1956$.

8. Heisen, H. A. et al.: Vitamin E und Nebennierenrindenfunktion. Dtsch. Med. Wschr., 76: 487-489, 1951.

9. Beckmann, R.: Vitamin $E$ in der Kinderheilkunde. Arch. f. Kinderheilkunde, 157: $7-23,1958$.

10. Menschik, Z.: Influence of Vitamin $\mathbf{E}$ on ovarian structure in mice. Quart. J. Exp. Physiol., 34: 97-123, 1948.

11. Suardi, L.: Effect of tocopherol administration on the hypophyseoadrenal system and the lymphopoietic parenchymas of the normal rat. Gazz. Int. Med. Chir., 63: 1877-1889, 1958.

12. Marvin, H. N., Dinning, J. S., and Day, P. L.: Erythrocyte survival in Vitamin E-deficient monkeys. Proc. Soc. Exp. Biol. Med., 105 473-475, 1960. 